\title{
FINANCIAL INNOVATIONS IN TESTING THE MECHANISM OF ENVIRONMENTAL INSURANCE AT INDUSTRIAL ENTERPRISES IN RUSSIA AND THE WORLD
}

\author{
KRUTOVA S.Lyubov ${ }^{1}$, KULIKOVSKY K. Mihail², ISAEV G.Kirill ${ }^{3}$ \\ ${ }^{1}$ Insurance and Social Economics Department, Financial Faculty, Financial University, Moscow (RUSSIA) \\ E-mails:Iskrutova@gmail.com;mkkulikovskij@fa.ru;kirill.isaev19981105@gmail.com
}

\begin{abstract}
The article provides an assessment of the development of the innovative mechanism of environmental insurance in the world and in Russia, identifies the main problems of regional development, and suggests a set of organizational and regulatory innovations for the introduction of the environmental insurance market. The article identifies the features of the implementation of environmental risk insurance in Russia and in the world and identifies the need to determine the key factors and indicators of sustainable development of the environmental insurance market. As a result, of the conducted research, a set of requirements for insurance companies planning to introduce the mechanism of imputed environmental insurance into their business processes is proposed. The financial and economic instruments for stimulating the greening of the economic activities of Russian industrial enterprises are justified.
\end{abstract}

Key words: Innovation, environmental insurance, financial mechanism, sustainable development, greening, industrial enterprises.

JEL: B26

DOI: 10.5937/intrev2103053K

UDC: 330.341.1(470:100)

005.35:502.1

005.21:001.895]:336

COBISS.SR-ID 55092233 


\section{INTRODUCTION}

Analysis of data on the state of the natural environment shows that the Russian economy has long functioned in the conditions of making most economic decisions while ignoring the generally accepted environmental requirements in other countries. If strategic decisions are not taken in the near future to adjust the course of the country's economic development, the Russian Federation will face a number of economic, social and environmental challenges that will become a serious obstacle to the successful development of the economy and society.

Currently, there is a direct correlation between the deterioration of the environmental situation in the country and the state of the economy. For the Russian regions, this factor is particularly significant due to the lack of development of the regional legislative framework for environmental protection, the lack or limited use of nature-saving technologies, and low ecological culture.

The slow and often absent environmental agenda in the Russian regions is mostly associated with such restrictions as:

- lack of approaches to a comprehensive understanding of environmental policy in the regions;

- the lack of effective legislative norms and regulations for enterprises that affect the environment, as a result-the construction of facilities that negatively affect the health of people, the quality of the natural environment;

- weak penetration of advanced environmental technologies and waste-free production in the regions due to the apparent high cost;

- aging population and outflow of qualified personnel to the central federal district;

- environmental degradation;

- not fully formed environmental legislation, which leads to insignificant amounts of payments for the negative impact on the atmospheric air by large enterprises.

\section{THEORETICAL ISSUES OF DISCUSSION OF SUSTAINABLE DEVELOPMENT}

Over the past few years, the discussion of the issue of sustainable development has finally consolidated its place in world politics. The endorsement of the concept of sustainable development has been reflected in a number of recent UN documents. In 2012, all UN member states supported the strategy for the future of humanity, based on the concept of sustainable development and the transition to a "green" economy [1]. In 2015, New York adopted the UN Sustainable Development Goals (SDGs) for all countries until 2030, which were formulated in the "Agenda for Sustainable Development for the period up to 2030" [2]. In December 2015, the Paris Agreement on Combating Climate Change was adopted, which provides for a radical greening of the world and national economies [3]. All UN member states supported these documents related to the concept of sustainable development. This allows us to say, according to S. N. Bobyleva [4], on sustainability as a single official paradigm of human development in the 21st century.

Today, we can talk about the gradual penetration of the concept of sustainable development in the regions (in December 2020, the Chelyabinsk region became the first region in Russia to adopt a regional environmental standard).

If we talk about the sustainable development of the regions, it is impossible not to touch on the key task-improving the level and quality of life of the population, which is inextricably linked with the indicators of the state of the ecological environment. Combining such indicators of the state of the regions as social, economic and environmental leads to the formation of an environmental-oriented strategy based on the mutual influence of different development factors.

Now we are seeing a shift in the spending of large businesses on environmental policy and environmental programs, but in general, in total, they do not exceed $1.9 \%$ of all revenue [5].

\section{FINANCING OF PROJECTS IN THE FIELD OF ENVIRONMENTAL PROTECTION}

As for the volume of environmental protection financing in the EU countries, since 2006, they have shown a dynamic growth (increasing by $36 \%$ over the period and amounting to 312.6 billion euros in 2019 [6]. The same dynamics is observed in the United States, where since the beginning of the operation of the 
Environmental Protection Agency, which provides environmental regulation in the country, its budget has grown 9 times. Despite the proposal of President Donald Trump to reduce it for the 2019 fiscal year, Congress approved a budget of $\$ 8.9$ billion (the maximum value for the period since 2011) [7].

According to the researchers [8], "it is necessary to modernize the insurance regulation system and the industry development strategy, taking into account the capabilities of regional insurers, which, as world practice shows, successfully work with specific and insignificant local and regional insurance interests in terms of potential insurance premiums, developing property and liability insurance for individuals, medium and small enterprises."There is a very large amount of data on fines in Rosprirodnadzor, but there are no major penalties. According to the audit and consulting network FinExpertiza, the number of penalties for environmental offenses in 2019 was the lowest in the last three years [8]. This hinders the incentive for companies to protect nature, since it is "cheaper for a successful business to pay the maximum penalty rate" than to comply with environmental regulations, because of low fines, companies often save on industrial safety.

\section{POSITIVE EFFECTS OF FOREIGN PRACTICE}

Therefore, there is a question about the priority of an environmental insurance policy over a fine. If it comes to court, then the registration of an insurance policy is more profitable than the imposition of a fine. In fact, "green" insurance is an economic tool, not an instrument of pressure, which meets the interests of the state and the industry. If there was, for example, an emergency oil spill at the enterprise, then it becomes the culprit and it is brought to justice, a fine is issued. But if there is a registered environmental insurance policy, then in case of an accidental emergency spill of petroleum products, you can trust an insurance company that will compensate for the damage to nature.

In foreign practice, where less attention is paid to fines, and more to compensation for damage, the mechanism of environmental insurance is developed. A characteristic aspect of Western legislation is the obligation of enterprises to inform about circumstances that with a high percentage of probability can lead to environmental pollution. Based on the strict liability regime provided for by the legislation, all economic entities prefer to insure their liability for environmental damage on a voluntary basis. Exists in some countries and mandatory insurance, but we are talking about small stakes and a very limited amount of insurance coverage.The transition of Russian legislation from the predominance of fines in the case of environmental pollution to the practice of judicial determination of damage will contribute to the development of compensation for real damage. This requires the addition of insurance as an effective mechanism for compensation for damage, although this may take a long time.

Currently, there is an attempt to create a "Disaster Data Bank" [9], which can become a database for calculating risks in environmental insurance and selecting the exact tariff rate. This database contains only documented information - decisions of Rosprirodnadzor, arbitration courts, acts, fines, expert examinations, accident reports, including those from the EMERCOM system. No policy - only data collected and structured into columns and cells according to certain parameters. Moreover, the data will be entered with some historical lag in order to teach the machine to issue benchmarks.

After analyzing the foreign experience of environmental risk insurance [10], the author suggests possible elements and directions of its use in the regions of Russia:

- it is important to create a culture of conscious environmental risk management in all areas of production activities, and not only for those who deal with hazardous substances;

- insurance companies should also better understand the needs of operators as potential harms associated with production activities - ;

- opportunities to use insurance to prevent risks can be used to encourage incremental changes by offering coverage and price incentives to reduce risk;

- for the formation of a portfolio of green finance, insurance policies can play a role;

- the development of close cooperation between the state, the public and the private sector would be a viable option to improve the coverage of public spending on environmental restoration associated with irresponsibility. 


\section{ANALYSIS OF THE CURRENT STATE OF THE STATE APPARATUS IN THE FIELD OF ENVIRONMENTAL INSURANCE}

Consequently, these provisions support the idea that it is necessary to present a financial mechanism for environmental insurance in the form of a Law, since at the moment there are no issues of applying a financial mechanism for compensation for environmental damage at the legislative level. This institute of environmental insurance, as V. A. Batadeev rightly notes in his article [11], "can become a powerful financial instrument in the hands of the state for solving many social and economic problems:

- security: sustainable development of the economy and social sphere;

- creation of: conditions for the restoration and expansion of the production potential of the national economy; cost-effective and efficient system for preventing losses at industrial and social facilities through the insurance mechanism and on this basis ensuring industrial safety; a favorable investment climate through the insurance system;

- social protection of citizens of the country;

- formation of long-term investment resources;

- strengthening the credit system by providing guarantees for the repayment of loans in the event of emergency events (catastrophes, accidents)."

The same position is held by R. T. Yuldashev, emphasizing that "to realize the opportunities of the insurance industry, active state support is needed, and the sooner the state realizes the role of insurance as a strategic sector of the economy, the sooner the transition to socially oriented market growth will be carried out in Russia" [12].In this article, the author conducted a SWOT analysis of the strengths and weaknesses of the introduction of imputed environmental insurance into the legislative mechanism (Fig. 1).

Strengths
1. Absence of a public insurance contract and
tariff regulation established by the state.
2. Clear formulations of the limit of the
insurer's liability for losses are being
developed, which allow the insurer to extend
coverage beyond the standard.
3. The cost of such insurance can be
attributed to the cost price, and this amount
will be deducted from the payment for excess
environmental pollution.

\section{Opportunities}

1. A number of incentives are introduced for enterprises entering into such insurance contracts (the incentive is to avoid the burden on the business and not pay fines).

2. Activation of competition: the policyholder will receive the desired service, focused exclusively on him.

3. It will make it possible in the long term to compensate for the environmental damage caused by the enterprise to the environment, and at the same time will not increase the financial burden on the enterprise itself.

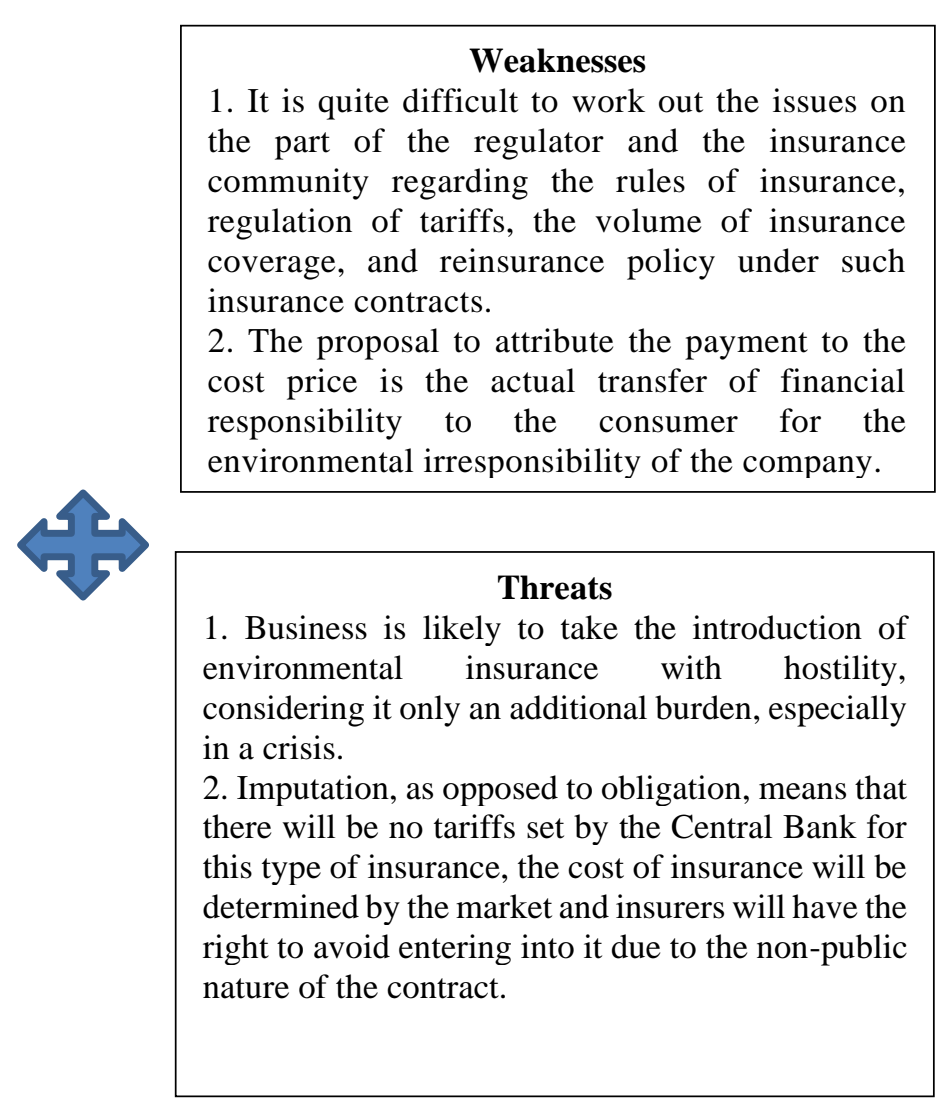

1. Business is likely to take the introduction of environmental insurance with hostility, in a crisis.

2. Imputation, as opposed to obligation, means that there will be no tariffs set by the Central Bank for this type of insurance, the cost of insurance will be determined by the market and insurers will have the right to avoid entering into it due to the non-public nature of the contract.

Fig. 1. SWOT analysis of the strengths and weaknesses of the introduction of imputed environmental insurance into the legislative mechanism

Note-compiled by the author. 
Currently, representatives of leading insurance organizations believe that environmental insurance should be carried out according to the imputed model, which implies the absence of a public insurance contract and tariff regulation established by the state [13].

The adoption of a special separate federal law on imputed environmental insurance under this model, on the one hand, will oblige enterprises to enter into environmental risk insurance contracts, and on the other - will not affect the economic essence of voluntary (commercial) insurance in the understanding that the amount of the insurance tariff is related to the interests of both parties.

The proposed concept assumes for each company several options for financial support of responsibility for environmental damage: insurance, bank guarantee or the creation of a reserve fund. The most important thing is a sufficient amount of coverage to be sufficient for full and unconditional compensation for the damage caused to nature. Thus, the SWOT analysis provides an understanding that imputed insurance is necessary without a fixed price and with a free choice of insurance company, with freedom in modeling coverage.

\section{CONCLUSION}

Thus, in order to integrate the risk management strategy into the business processes of industrial enterprises, the insurance company needs to conduct a thorough assessment of the risk, impact, responsibility and cost-effectiveness of risk reduction measures. They should choose a strategy based on the probability of danger and the magnitude of the impact. For low-probability / low-impact risks, businesses may choose to maintain risk through financial guarantees, deposits, and funds. For this purpose, there is an accumulation of financial reserves in the event of environmental damage, providing financial opportunities for the restoration of the environment. For a higher level of risk, the best and often cheaper option is to transfer the risk, in exchange for monetary compensation, avoiding the impact of potentially unrecoverable losses.

To reduce the negative impact on the environment, we need an integrated approach and infrastructure. The introduction of the environmental insurance mechanism will facilitate the issuance of green and social bonds included in the Sustainable Development Sector on the Moscow Exchange. If we add a social block, the quality of regional governance, the topic of green finance (including the proportions of the budget expenditure) and the result of monitoring physical risks (accidents) to this, of course, high - quality stuffing, then we can get a real ESG standard for the region, taking into account all relevant approaches.

Given the adverse events that are taking place in Russia in the field of technological disasters (emergency spill diesel Norilsk), you need to start to consider them, digitize, and on this basis to create a risk assessment methodologies and keeping them in future green financial strategies. When all the information is brought together, it turns out that green funding is directed to those objects or to those companies that endlessly violate environmental legislation. Then the natural asset will have a specific value.

\section{REFERENCES}

[1] The future we want. The final document of the UN Conference. Rio de Janeiro. 2012. [Electronic resource]. - Retrieved from: http://www.uncsd2012.org/ (date of access 2021-02-20).

[2] Outcome document of the United Nations Summit for the Adoption of the post-2015 development agenda: Transforming our world: The 2030 Agenda for Sustainable Development. [Electronic resource]. - Retrieved from: http://www.un.org/ga/search/view_doc.asp?symbol=A/RES/70/1\&Lang=R (date of access 2021-02-20).

[3] The Paris Agreement under the United Nations Framework Convention on Climate Change. UN, Paris, 2015.

[4] Bobylev S.N. (2016). Report on human development in the Russian Federation for 2016 / edited by L. M. Grigoriev and S. N. Bobylev. Moscow: Analiticheskii centr pri Pravitelstve RF [Analytical center under the government of the Russian Federation]. -298 p. 
[5] Rating "Leaders of Russian business in environmental spending", published by RAEX [Electronic resource]. - Retrieved from: https://raex-rr.com/country/RAEX-600/ecology_leaders (date of access 2021-02-20).

[6] Statistical database Eurostat. [Electronic resource]. - Retrieved from: https://ec.europa.eu/eurostat/data/database (date of access 2021-02-20).

[7] Content of the United States Environmental Protection Agency : official website. - URL: https://www.epa.gov (date of access 2021-02-20).

[8] Tsyganov A.A. (2018). Strahovoj rynok Rossijskoj Federacii. Regional'nyj aspekt [Insurance market of the Russian Federation. The regional aspect] / Tsyganov A.A., Kirillova N.V. // Ekonomika regiona [Regional economy], 14, 1270-1281.

[9] Expert-analytical platform " Infrastructure and Finance for Sustainable development». [Electronic resource]. - Retrieved from: www.infragreen.ru (date of access 2021-02-20).

[10] Porrini D. Risk Classification Eciency and the Insurance Market Regulation // Risks. — 2015. No 3. - Pp. 445-454., 445-454.

[11] Batadeev V.A. (2014). Rol' i funkcii strahovogo kapitala v koncepcii ustojchivogo razvitiya ekonomiki [The role and functions of insurance capital in the concept of sustainable economic development] // Uchenye zapiski rossijskoj akademii predprinimatel'stva [Scientific Notes of the Russian Academy of Entrepreneurship], 39, 137-151.

[12] Uldashev R.T. (2015). Nekotorye problemy gosudarstvennogo regulirovaniya strahovaniya [Some problems of state regulation of insurance] // Risk-menedzhment v ekonomike ustojchivogo razvitiya [Risk management in the economy of sustainable development] / Materialy III Vserossijskoj nauchno-prakticheskoj konferencii studentov i molodyh uchenyh s mezhdunarodnym uchastiem [Thesis of the III All-Russian Scientific and Practical Conference of Students and Young Scientists with International Participation] / edited by A. I. Raszgivina, I. T. Sabirova, A. R. Gapsalamova, S. V. Husainovoy. PP. 9-10.

[13] The All-Russian Union of Insurers has taken the initiative to make liability insurance for causing environmental damage to nature imputed. [Electronic resource]. - Retrieved from: https://rg.ru/2020/10/12/strahovshchiki-predlozhili-vmenit-ekologicheskij-ushcherbkompaniiam.html (date of access 2021-02-20).

\section{Article history:}

Received 16 July 2021

Accepted 1 December 2021 